В.М. Михальчук, З.В. Гбур, К.В. Щиріна, О.О. Черненко

Національна медична академія післядипломної освіти імені П.Л. Шупика, Київ

\title{
Соціологічне дослідження ефективності роботи багатопрофільної приватної клініки
}

У статті досліджено методику проведення соціологічного дослідження з ефективності роботи багатопрофільної приватної клініки. Визначено предметне поле соціологічного оцінювання функціонування приватної медицини. Соціологічне дослідження повинно базуватися на основі використання компетентнісного підходу, згідно з яким основою якісного медичного обслуговування населення є система різнопланових компетенцій медичного працівника. Найпоширеніші методи соціологічного дослідження - анонімні анкетування, інтернет-опитування, формування фокус-груп, проведення особистих інтерв'ю. Загалом соціологічне дослідження забезпечує формування напрямків оптимізації роботи приватної клініки та вирішення проблем, пов'язаних із рівнем задоволення населення медичними послугами, задоволеності працівників організацією приватної медицини. Визначено етапи проведення соціологічного дослідження. Для достовірності результатів соціологічного дослідження доцільно використовувати методи обробки даних математичної статистики. Для обробки результатів доцільно використовувати параметричні методи визначення основних статистичних характеристик.

ключові слова: багатопрофільна приватна клініка, соціологічне дослідження, ефективність, анкетування медичного персоналу, медичні послуги.

\section{Актуальність проблеми}

Запровадження нових організаційних форм надання медичної допомоги та створення нових структур у системі охорони здоров'я (СО3) потребує комплексного й ретельного аналізу досвіду їх роботи з метою оцінки можливості та доцільності його подальшого використання. Важливим інформаційним джерелом для здійснення цього аналізу є результати соціологічних досліджень, які забезпечують зворотний зв'язок із пацієнтами та дозволяють оцінити їх задоволеність наданою медичною допомогою. Моніторинг задоволеності пацієнтів має бути постійною складовою аудиту якості медичної допомоги та її соціальної ефективності. Соціологічна оцінка задоволеності населення медичною допомогою $€$ також необхідною умовою для здійснення науково обґрунтованої управлінської діяльності у СОЗ і однією зі складових планування лікувально-профілактичних заходів, розроблення організаційних форм і методів роботи, а також методом контролю за ефективністю його діяльності щодо збереження здоров'я населення. Соціологічна оцінка задоволеності населення медичною допомогою важлива інформаційна складова для здійснення науково обґрунтованої управлінської діяльності у СО3 (Решетников А.В., 2007).

\section{Аналіз останніх досліджень та публікацій}

У низці праць на основі соціологічного опитування виявлено тенденції щодо розвитку державної та приватної медицини в Україні. Дослідженням напрямків оптимізації роботи закладів охорони здоров'я на основі проведення соціологічного опитування медичного персоналу та населення займалися багато авторів (Лашкул З.В., Курочка В.Л., 2014; Матюха Л.Ф. та співавт., 2014; Савчук О.В., 2014а; б; Серікова Т.Є., 2014; Харитонюк Р.О., 2014; Жилка Н.Я., Кудря А.В., 2015; Шевченко М.В., 2016; Заюков І.В., 2017; Толстанов О.К. та співавт., 2017; Князьков С.Г., 2018). Проте на сьогодні відсутні дослідження щодо методології проведення соціологічних досліджень ефективності роботи багатопрофільної приватної клініки (БПК), які дали би змогу виявити переваги та недоліки, можливі напрямки оптимізації діяльності.

Мета - формування методології соціологічного дослідження ефективності роботи багатопрофільної приватної клініки.

\section{Виклад основного матеріалу}

Упродовж останніх десятиліть триває розширення предметного поля соціології. Один із таких піонерських та водночас практично орієнтованих напрямків - соціологічне дослідження й оцінка функціонування СО3, зокрема приватної медицини.

Оцінювання включає:

- соціологічний аналіз таких явищ, як медикалізація;
- соціологічний аналіз і оцінку медичної, економічної та соціальної ефективності функціонування приватної клініки;

- соціологічний аналіз ролі держави та державної політики щодо розвитку приватної медицини;

- соціологічний аналіз інституційних пасток у процесі функціонування приватного медичного сектору;

- соціологічний аналіз чинників прийняття рішень про вибір асортименту медичних послуг (МП) відповідно до потреб населення та проблематики рівності доступу до якісних МП населення.

Предметне поле соціологічного оцінювання функціонування приватної медицини охоплює таке коло питань:

- дослідження поінформованості громадян про спосіб організації забезпечення населення МП;

- виявлення чинників вибору медичного закладу та впливу механізмів надання приватних МП на поведінку споживачів послуг приватних клінік;

- оцінка ефективності заходів із реформування приватного сектору особами та групами, причетними до цих процесів;

- з'ясування ступеня задоволеності споживачів приватних МП якістю, ціною, рівнем послуг тощо.

У моніторингу якості МП впродовж останніх років набув поширення так званий компетентнісний підхід, згідно з яким основою якісного медичного обслуговування населення є система різнопланових компетенцій медичного працівника.

В українській соціології є прогалина у наукових розробкаху такій важливій галузі, як соціологія медицини. Незважаючи на визнання, що здоров'я - одна з найважливіших складових соціального життя, яка $€$ фундаментом для формування та організації практично всіх сфер життєдіяльності людини та соціуму, широкого спектра фундаментальних соціологічних досліджень за медичною тематикою в Україні не спостерігається. Майже відсутній і певний соціологічний супровід системи управління медичним комплексом, хоча всі моніторингові дослідження на загальноукраїнському та регіональному рівнях, за оцінками респондентів, свідчать про занадто важливу роль проблеми медичного обслуговування. Поява, а потім і бурхливий розвитокприватного сектору медицини тільки посилює необхідність більш чіткого розуміння, яким чином у період стрімкого поширення новітніх технологій повинно здійснюватися управління такою важливою і делікатною сферою, як медицина. Досі усі ці питання знаходяться на периферії уваги сучасної української соціології.

На сайті Соціологічної асоціації України серед усіх представлених соціологічних досліджень лише одне стосується охорони здоров'я та пов'язане з думками і поглядами населення України щодо охорони здоров'я та інших питань (Київський міжнародний інститут соціології, 2019). Опитування проводили методом особистих інтерв'ю. 
Прикладами проведення соціологічного дослідження є низка робіт (Лашкул З.В., Курочка В.Л., 2014; Матюха Л.Ф. та співавт., 2014; Савчук О.В., 2014а; б; Харитонюк Р.О., 2014; Жилка Н.Я., Кудря А.В., 2015; Шевченко М.В., 2016; Заюков І.В., 2017; Толстанов О.К. та співавт., 2017; Князьков С.Г., 2018), в яких використано анкетування, фокус-групи та опитування шляхом електронної розсилки. У роботі З.В. Лашкул, В.Л. Курочки (2014) використано методи варіаційної статистики на основі даних анкетування для оцінювання ставлення 114 лікарів до проблем профілактики серцевосудинних захворювань. Встановлено, що більшість респондентів вважає спосіб життя і зусилля самої людини провідними чинниками здоров'я населення. Таким чином, опитування дає змогу визначити проблеми, які існують у закладах охорони здоров'я. Методи проведення соціологічного дослідження ефективності роботи БПК показані на рис. 1.

Соціологічні дослідження націлені на вирішення суто практичних питань соціального життя. Для соціології всі її проблеми є терміновими, такими, що потребують негайного реагування, оскільки стосуються актуальних інтересів сучасного суспільства (Требін М.П. (ред.), 2010). У соціології медицини застосування методології аналізу стану служб охорони здоров'я шляхом анкетування по суті сприяє зміні ї̈ парадигми (Сливка Л.В., Сасс І.Я., 2012).

Одним із основних методів соціологічних досліджень, які використовують у СО3, є анкетування. Особливість цього методу його анонімність (особистість респондента не реєструють, фіксують лише відповіді), що дозволяє отримати найточнішу інформацію (Вербець В.В. та співавт., 2009).

Соціологічний метод дослідження використовують для:

- оцінки рівня задоволеності населення якістю МП та організацією роботи приватної клініки, їх відповідністю сучасним потребам населення (Савчук О.В., 2014а; б);

- оцінки ставлення різних категорій населення до хвороб та організації медичної допомоги хворим;

- дослідження того, як заклади охорони здоров'я оцінюють стан та перспективи МП різного рівня;

- оцінки якості МП та їх відповідності міжнародним стандартам;

- оцінки фінансового забезпечення медичних закладів;

- оцінки забезпеченості обладнанням та інформаційними системами;

- оцінки ступеня професійної підготовки персоналу

- оцінки ефективності нормативно-правової бази;

- характеристики стану організації МП населенню.

Соціологічний метод може також бути використаний для дослідження ставлення організаторів охорони здоров'я, медичних працівників і населення до проблем системи фінансування охорони здоров'я та шляхів її реформування (Шевченко М.В., 2016).

Соціологічне дослідження може передбачати проведення опитування серед різних контингентів респондентів - лікарів та пацієнтів. Опитування лікарів може проводитися з метою визначення рівня їх обізнаності та компетентності в певній галузі діяльності, за спеціально розробленою анкетою.

Побудова анкетних опитувальників є типовою і містить декілька структурних складових (Харитонюк Р.О., 2014):

- звернення до респондента, отримання поінформованої згоди на участь у дослідженні;

- паспортну частину;

- основний блок із цільовими запитаннями

Останні за результатами отриманих відповідей надають змогу зрозуміти діяльність респондентів щодо запобігання захворюванням, їх наступності в роботі з лікарями, спроможності правильно будувати тактику при виявленні захворювань.

Соціологічне дослідження серед пацієнтів закладів охорони здоров'я може також використовуватися з метою вивчення задоволеності основних користувачів послуг медичного закладу. Цільові запитання цього інструменту дослідження дозволяють оцінити рівень довіри респондентів до лікарів із питань лікування та профілактики хвороб, внесок лікаря у поінформованість пацієнтів із питань запобігання хворобам, ставлення опитаних до проведення профілактичних щеплень тощо.

Об'єктивність отриманої соціологічної інформації забезпечується шляхом формування репрезентативних вибірок, відповідних визначеним генеральним сукупностям цільових груп, охоплених дослідженням.

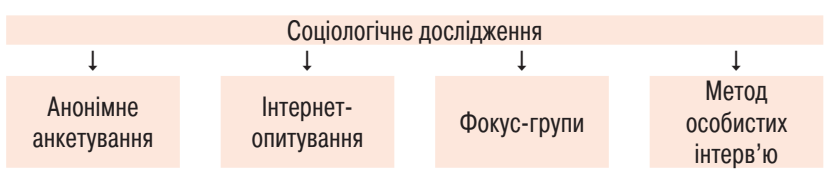

Рис. 1. Класифікація методів соціологічного дослідження ефективності роботи БПК

Розроблення програми та робочого плану соціологічного дослідження Формулювання гіпотез щодо наявних проблем, мети, об'єкта та завдань Формування репрезентативної вибірки Ідентифікація та розроблення анкети респондентів

$\begin{array}{cc}\text { Проведення опитування } \\ \text { Перевірка анкети } & \text { Розрахунок середніх величин } \\ \text { на правильність } & \text { та стандартних відхилень }\end{array}$

\section{Аналіз отриманих даних та формування шляхів вирішення} проблем/напрямків оптимізації роботи

Рис. 2. Схема проведення соціологічного дослідження приватної клініки (складено на основі: Горачук В.В. та співавт., 2016)

Статистична обробка матеріалів соціологічного дослідження передбачає використання методів статистичного групування, табличного зведення, аналізу абсолютних та відносних рядів розподілу, оцінки статистичної вірогідності відмінності результатів соціологічного опитування респондентів у різних приватних клініках (за критеріями Пірсона $\chi^{2}$, кореляції Спірмена $r_{s}$, Стьюдента, $\chi^{2}$ тощо) (Харитонюк Р.О., 2014; Шевченко М.В., 2016).

Для встановлення залежностей між досліджуваними сукупностями використовують кореляційний, регресійний та факторний аналіз. Вірогідність відмінностей показників та їх змін оцінюють з використанням критерію t Стьюдента; наявність кореляційного зв'язку між порівнюваними показниками - r, частку коливань результативної ознаки, зумовленої коливанням факторної ознаки коефіцієнтом детермінації $\left(\mathrm{R}^{2}\right)$. Для виявлення сили впливу досліджуваних факторних ознак застосовують метод побудови й аналізу багатофакторних логістичних моделей регресії.

Для обробки результатів соціологічного дослідження доцільно використовувати параметричні методи визначення основних статистичниххарактеристик: середнє значення (М), похибка середньогозначення (m), стандартне відхилення (d), медіанне значення (Me); ланцюгових та базисних показників ряду динаміки (абсолютний приріст, темпи приросту, зростання, абсолютне значення 1\% приросту) тощо. Для обробки та аналізу результатів дослідження доцільно використовувати пакети прикладних програм, в яких реалізовані статистичні методи обробки даних: «MS Excel», «Statistica», «Statgrapfica» (Савчук О.В., 2014a).

У процесі опитування потрібно дотримуватися важливої умови проведення експертиз - попереднє інформаційне забезпечення експертів та відкрита дискусія з подальшим опитуванням за допомогою анкет. Запитання анкети слід сформульовувати у загальноприйнятих термінах. Відповіді можна формувати за типом «так», «ні». Для їх обробки застосовують альтернативний аналіз, який включає підрахунки в абсолютних та відносних величинах. Результати дослідження підлягають статистичній обробці, а такожаналізу і пояснення.

Репрезентативність вибіркових сукупностей може бути забезпечена як типологічними властивостями вибірок, так і розрахунком необхідного обсягу спостережень.

Визначення обсягу вибіркової сукупності можна здійснювати за формулою (Горачук В.В. та співавт., 2016):

$$
n=\frac{t^{2} p q N}{N \Delta^{2}+t^{2} p q},
$$

де $n$ - обсяг вибіркової сукупності, $t$ - коефіцієнт унормованого відхилення, або довірчий коефіцієнт $(t=2), p-$ ймовірність наявної ознаки $(p=0,5), q-$ ймовірність відсутності ознаки $(q=1-p=0,5)$; $N$ - обсяг генеральної сукупності, $\Delta-$ гранично припустима помилка у медико-соціологічних дослідженнях (максимальна величина припустимої помилки становить $\pm 5 \%$, або 0,05).

Нагадаємо, що при обсязі генеральної сукупності >5000 осіб обсяг репрезентативної вибірки становить не менше 400 од. за умови помилки у 5\% (Горачук В.В. та співавт., 2016). 
У конструюванні вибірки можуть бути використані метод цілеспрямованої вибірки, метод снігової кулі або їх поєднання.

На 1-му етапі проведення соціологічного дослідження здійснюють такі кроки:

- формування репрезентативної вибірки з об'єктів дослідження;

- визначення правил відбору респондентів;

- розроблення анкети соціологічного опитування та її тиражування;

- безпосереднє проведення опитування;

- підготовка звіту про результати опитування;

- представлення звіту керівництву закладу охорони здоров'я для використання при прийнятті управлінських рішень з поліпшення медичного обслуговування населення (рис. 2).

Отримання кількісних вимірювань забезпечується застосовуванням цифрової шкали (10 поділок), оскільки роздрібненість метрики - чутливість шкали - прямо пов'язана з точністю вимірювань.

Для успішності процедури безпосереднього опитування співробітників велике значення мають дотримання принципу анонімності та умови її забезпечення: у позаробочий час, у світлому тихому приміщенні, з розміщенням кожного з респондентів за окремим столом, забезпеченням бланком анкети, олівцями, ручками. Бажано проводити опитування у межах структурного підрозділу (відділення). Складовими опитування є також інструктаж респондентів відповідальними особами щодо правил заповнення анкет, надання письмової інформованої згоди на опитування, яка $є$ складовою анкети, і нарешті - відповіді на пункти анкети.

\section{Висновки}

Проведене дослідження дало змогузапропонувати методологію проведення соціологічного дослідження ефективності роботи БПК. Цілі дослідження - визначення ефективності роботи медичного персоналу, рівня задоволеності населення (пацієнтів) роботою клініки, рівня організації медичної допомоги, оцінки ступеня професійної підготовки персоналу тощо. Найпоширеніші методи соціологічного дослідження - анонімні анкетування, інтернет-опитування формування фокус-груп, проведення особистих інтерв'ю. Загалом соціологічне дослідження забезпечує формування напрямків оптимізації роботи приватної клініки та вирішення проблем, що пов'язан з рівнем задоволення населення МП, задоволеності працівників організацією приватної медицини. Визначено етапи проведення соціологічного дослідження. Для достовірності результатів дослідження доцільно використовувати методи обробки даних математичної статистики. Для обробки результатів соціологічного дослідження доцільно використовувати параметричні методи визначення основних статистичних характеристик.

\section{Список використаної літератури}

Вербець В.В., Субот О.А., Христюк Т.А. (2009) Соціологія: Навч. посіб. Кондор, Київ, 550 с.

Горачук В.В., Вороненко Ю.В., Гойда Н.Г. та ін. (2016) Організація соціологічних опитувань пацієнтів/іх представників і медичного персоналу у закладах охорони здоров'я. Методичні рекомендації Міністерства охорони здоров'я України. Сімейна медицина, 5(67): 118-125.

Жилка Н.Я., Кудря А.В. (2015) Рівень задоволеності та інформованості населення щодо послуг лікаря загальної практики - сімейного лікаря (інтернет-опитування). Україна. Здоров'я нації, 4: 66-69.

Заюков І.В. (2017) Дослідження мотивів звернень зайнятого населення за медичною допомогою: самозберігаючий аспект. Економіка, 6(34): 70-78.

Київський міжнародний інститут соціології (2019) Думки і погляди населення України щодо охорони здоров'я та інших питань (http://sau.in.ua).

Князьков С.Г. (2018) Інструментарій соціологічного вивчення компетенцій фармпрацівників у кроснаціональному вимірі. Вісн. Львів. ун-ту, 12: 16-31.

Лашкул 3.В., Курочка В.Л. (2014) Соціально-гігієнічне дослідження факторів ризику серцево-судинних захворювань серед лікарів різних фахових груп, з'ясування ставлення лікарів до проблем профілактики. Запорож. мед. журн., 3: 23-25.

Матюха Л.Ф., Хіміон Л.В., Бурма В. та ін. (2014) Аналіз результатів соціологічного дослідження з оцінки доступності і повноти первинної медичної допомоги, що надається лікарями первинної ланки. Зб. наук. праць співробіт. НМАПО імен П.Л. Шупика, 23(1): 467-477.

Решетников А.В. (2007) Проведение медико-социологического мониторинга Политехресурс, Москва, 160 с.

Савчук О.В. (2014а) Соціологічне дослідження як елемент інформаційної бази для оптимізації діяльності стоматологічних закладів. Вісн. пробл. біол. мед. . 3: 87-91.

Савчук О.В. (2014б) Характеристика стану організації стоматологічної допомоги населенню за матеріалами соціологічного дослідження. Зб. наук. праць співробітників НМАПО імені П.Л. Шупика, 23(3): 143-150.
Серікова Т.є. (2014) Технологічна складова розвитку сучасної української медицини: управлінські аспекти. Сучасні суспільні проблеми у вимірі соціології управління: Зб. наук. праць ДонДУу, с. 137-143.

Сливка Л.В., Сасс І.Я. (2012) Соціологія та медична соціологія. Навчальнометодичний посібник для студентів вищих медичних навчальних закладів України III-IV рівнів акредитації. Івано-Франківськ, 125 с.

Толстанов О.К., Михальчук В.М., Кравченко В.В. (2017) Результати соціологічного опитування пацієнтів комунальних та приватних консультативно-діагностичнихцентрів м. Києва. Зб. наук. праць співробіт. НМАПО імені П.Л. Шупика, 27: 340-351.

Требін М.П. (ред.) (2010) Соціологія. Право, Харків, 217 с.

Харитонюк Р. О. (2014) Медико-соціальне обгрунтування концепції оптимізації медичної допомоги інфекційним хворим на регіональному рівні. Автореф. дис. ... канд. мед. наук. Київ, 25 с.

Шевченко М.В. (2016) Медико-соціальне обгрунтування нової системи фінансування охорони здоров'я в Україні. Автореф. дис. докт. мед. наук. Харків, 45 с.

\section{Социологическое исследование эффективности работы многопрофильной частной клиники \\ В.Н. Михальчук, З.В. Гбур, Е.В. Щирина, Е.А. Черненко}

Резюме. В статье исследована методика проведения социологического исследования по эффективности работы многопрофильной частной клиники. Определено предметное поле социологической оценки функционирования частной медицины. Социологическое исследование должно базироваться на основе использования компетентностного подхода, согласно которому основой качественного медицинского обслуживания населения является система разноплановых компетенций медицинского работника. Наиболее распространенные методы социологического исследования-анонимныеанкетирования, интернет-опросы, формирование фокус-групп, проведение личных интервью. Вцелом социологическое исследование обеспечивает формирование направлений оптимизации работы частной клиники и решения проблем, связанных с уровнем удовлетворения населения медицинскими услугами, удовлетворенности работников организацией частной медицины. Определены этапы проведения социологического исследования. Для достоверности результатов социологического исследования целесообразно использовать методы обработки данных математической статистики. Для обработки результатов социологического исследования целесообразно использовать параметрические методы определения основных статистических характеристик.

Ключевые слова: многопрофильная частная клиника, социологическое исследование, эффективность, анкетирование медицинского персонала, медицинские услуги.

\section{A sociological study of the effectiveness of a multidisciplinary private hospital \\ V.M. Mikhalchuk, Z.V. Gbur, K.V. Shchirina, 0.0. Chernenko}

Summary. The article explores the methodology of conducting a sociological research on the effectiveness of a multidisciplinary private clinic. The subject field of sociological assessment of functioning of private medicine has been determined. The sociological research should be based on the use of a competent approach, according to which the basis of quality medical care of the population is the system of diversified competencies of the medical worker. The most common methods of sociological research are anonymous surveys, conducting online surveys, forming focus groups, conducting personal interviews. In general, the sociological survey provides the formation of directions for optimizing the work of a private clinic and solving problems related to the level of satisfaction of the population with medical services, satisfaction of employees with the organization of private medicine. The stages of sociological research are determined. It is advisable to use mathematical statistics data processing methods for the reliability of the study results. It is advisable to use parametric methods for determining the main statistical characteristics to process the results of a sociological survey.

Key words: multidisciplinary private clinic, sociological research, efficiency, questionnaire of medical staff, medical services.

Адреса для листування:

Гбур Зоряна Володимирівна

04112, Київ, вул. Дорогожицька, 9

Національна медична академія післядипломної освіти імені П.Л. Шупика,

кафедра управління охороною здоров'я

E-mail: ernest-natan@ukr.net 